\title{
FULL DAY SCHOOL SEBAGAI LAYANAN PENDIDIKAN PENGASUH PENGGANTI ORANGTUA BAGI ANAK DI TAMAN KANAK-KANAK KOTA CIREBON
}

\author{
Fiqih Rachmalia Astrini \\ ikaamalia@gmail.com, Fiqihra.edu@gmail.com \\ Universitas Muhammadiyah Cirebon
}

\begin{abstract}
Berkembangnya full day school (FDS) pada jenjang pendidikan anak usia dini memberikan angin segar bagi para orang tua yang keduanya bekerja, berkembangnya $F D S$ juga didasari oleh semakin banyak orang tua yang bekerja sehingga tidak dapat menjaga anaknya setelah anak pulang sekolah. FDS menjadi layanan pendidikan bagi anak dalam bentuk pengasuhan di lingkungan sekolah setelah jam belajar berlangsung. Karena FDS dianggap memiliki peran pengasuh pengganti orang tua bagi anak dalam pengasuhan, banyak orang tua yang menjadi lalai terhadap kewajiban utama mendidik anak karena menganggap anaknya telah mendapatkan pendidikan dari guru-guru di sekolah. Penelitian ini menggunakan pendekatan kualitatif dengan metode fenomenologi. Responded dalam penelitian ini yaitu tiga guru dan tiga orang tua siswa. Alat pengumpulan data yang digunakan dalam penelitian ini adalah observasi dan wawancara tidak terstruktur. Adapun analisis data yang digunakan yaitu analisis data grounded theory. Berdasarkan penelitian diperoleh hasil bahwa $F D S$ menjadi peran pengasuh pengganti bagi orang tua dalam mendidik anak, namun orang tua menjadi melalaikan kewajiban utama mereka dalam mendidik anak karena menganggap anaknya telah mendapatkan cukup pendidikan selama di sekolah bersama guru.
\end{abstract}

Keywords: full day school, pendidikan anak usia dini, anak usia dini, pengasuh pengganti, peran pengasuh pengganti.

\section{PENDAHULUAN}

Fullday school (FDS) pada jenjang pendidikan anak usia dini, merupakan program di sekolah yang dilakukan setelah jam belajar dilakukan secara terencana, yang sifatnya memberikan layanan pendidikan dalam pengasuhan (Cooper 2010, Demircan 2014, Ellicker 1997) memlalui kegiatan
FDS diharapkan dapat memberikan layanan pendidikan bagi anak-anak yang orangtuanya bekerja dan tidak dapat mendampingi anak setelah jam belajar di sekolah. Lebih lanjut Walston (2005), dan Reynolds (2014) memaparkan tentang bagaimana pelaksanaan $F D S$ akan terlaksana dengan baik dan akan memberikan hasil yang baik memerlukan kerjasama antara orangtua dan pihak sekolah serta kontinuitas dari proses pendidikan itu sendiri. 
Proses

perkembangan

behavioris rangsangan dari lingkungan. Salah satunya Thorndike (1913) yang memaparkan peristiwa terbentuknya asosiasi antara peristiwa-peristiwa yang disebut stimulus dengan respon yang diberikan atas stimulus tersebut. Stimulus yang didapatkan seorang anak saat $F D S$ dari guru sebagai pengasuh berupa asah yang kemudian anak memberikan respon berupa perkembangan anak.

Kegiatan $F D S$ meliputi
berbagai aspek yang dapat mengembangkan potensi dalam diri anak baik secara kognitif, sosial emosi, sikap mandiri dan kreativitas anak. Seperti yang diungkapkan oleh Woodland (2008), dan Vanderloo (2016) bahwa kegiatan FDS sangat baik dilakukan jika program pelaksanaan terencana, dilaksanakan dengan pengawasan namun berjalan natural sehingga tidak ada tekanan bagi anak dimana jangka waktu belajar mereka di sekolah menjadi lebih panjang dan adanya dukungan dari orangtua (Urbel 2013, Walston 2005, Maynard 2013). Lebih lanjut Maynard (2013) memaparkan pendidik dalam memberikan pengasuhan adanya dukungan kepada anak untuk dapat belajar melalui bermain yang bermakna, menarik, dan merangsang imajinasi, kreativitas anak untuk melakukan, mengekplorasi, memanipulasi, dan menemukan inovasi sesuai dengan minat dan gaya belajar anak.

Terdapat beberapa penelitian terdahulu yang pernah dilakukan oleh Leng (2014), Shen (2009), Williams (2014) dimana penelitian tersebut menunjukan Minimnya peran serta

orangtua dalam memberikan pengasuhan kepada anak sehingga membuat anak mengalami gangguan emosional berupa rasa tidak diperhatikan oleh orangtua yang sudah seharian bekerja. Beberapa perilaku orangtua di rumah yang dianggap sederhana nanum itu mengabaikan anak dijelaskan oleh Williams (2014) dengan tidak menanyakan apa yang dilakukan anak saat belajar di sekolah itu akan sangat berdampak kepada anak. Seharunya melalui lingkungan keluarga terutama orang tua memberikan kenyamanan pada anak walaupun anak sudah dianggap cukup mendapatkan pendidikan selama di sekolah. Hubungan yang sehat antara orang tua dan anak akan memfasilitasi perkembangan anak, sedangkan hubungan yang tidak sehat mengakibatkan anak mengalami kesulitan dalam perkembangannya, (Baradja 2005)

\section{METODOLOGI}

Pendekatan dalam penelitian ini adalah pendekatan kualitatif dengan menggunakan metode penelitian fenomenologi, peneliti memilih metode fenomenologi dalam penelitian ini karena ingin melihat secara mendalam dan menyeluruh menurut Bungin (2010), Creswell (2013) khususnya dalam penelitian ini yaitu perihal full day school sebagai layanan pendidikan pengasuh pengganti orang tua, bagaimana proses berlangsungnya $F D S$, hingga dampak dari peran $F D S$ sebagai layanan pengasuh pengganti orang tua itu sendiri. Responden dalam penelitian ini yaitu tiga guru dan tiga orang tua siswa yang mengikuti $F D S$. 
Sedangkan teknik analisis data menggunakan teknik analisis grounded theory. Adapun alat yang digunakan dalam pengumpulan data dalam penelitian ini menggunakan observasi dan wawancara tidak terstruktur, sebagai key instrumen dalam penelitian ini peneliti mengembangkan pertanyaan yang bersifat terbuka untuk dapat menggali informasi sesuai kebutuhan penelitian.

\section{HASIL DAN PEMBAHASAN}

Berdasarkan hasil penelitian diperoleh hasil bahwa $F D S$ dapat menjadi layanan pengasuh pengganti orang tua dalam mendidik anak di lingkup pendidikan, FDS membantu orang tua dalam memberikan pengasuhan yang tidak dapat mereka berikan kepada anak selama sedang bekerja. Lingkup yang dilakukan dalam kegiatan FDS sendiri berupa pengembangan diri melalui berbagai kegiatan bermain yang dapat memberikan stimulus untuk dapat mengembangkan berbagai aspek perkembangan. Namun sayangnya hasil penelitian juga menunjukkan adanya kelalaian dari orang tua dalam memberikan pengasuhan kepada anak saat anak sudah berada di rumah karena orang tua menganggap anak telah cukup belajar selama seharian di sekolah. Tidak di pungkiri juga orang tua sudah lelah bekerja sehingga ketika di rumah, menginginkan waktu istirahat untuk mempersiapkan diri bekerja hari berikutnya. Padahal seharusnya orang tua tidak memberikan tanggung jawab secara penuh kepada pihak sekolah khususnya guru dalam mendidik dan memberikan pengasuhan kepada anak mereka, sekolah $F D S$ hanya menjadi sarana layanan pendidikan untuk membantu anak mengembangkan diri, seperti dalam penelitiannya Brannon (2001), Cooper (2010) mengungkapkan keluarga khususnya orang tua merupakan orang yang paling bertanggung jawab atas pendidikan anaknya, hal ini dimaksud bahwa orang tua tidak dapat melalaikan kewajibannya dalam mendidik anak sekalipun anak mengikuti kegiatan FDS. Membangun hubungan dengan anak melalui komunikasi positif menjadi hal penting baik untuk hubungan antara ibu dan anak juga untuk emosional anak, dimana anak akan merasa diperhatikan oleh orang tuanya walaupun orang tuanya sibuk bekerja (Cryan 1992, Fenner 2016). 


\section{REFERENSI}

Asrori. (2004). Metodologi Penelitian Kualitatif. Bandung: Alfabeta.

Baradja, A. (2005). Psikologi perkembangan: Tahapan-tahapan dan aspekaspeknya. Jakarta: Studia Press.

Fenner, Ashley. (2016). Exploration of the Mechanisms of Change in Constructs From Self-Determination Theory and Quality of Life During a Multidisciplinary Family-Based Intervention Adolescents. Journal of Sport \& Exercise Psychology. (38) 6. 59-68.

Creswell, W. John. (2010). Research Design. Pendekatan Kualitatif, Kuantitatif dan Mixed. Yogyakarta: Pustaka Pelajar.

Cryan, John. Sheehan, Robert. Whiecel. Hedden. (1992). Succes Outcomes of Full Day Kindergarten: More Positive Behaviour and Increased Achievement in theYears after. Early Childhood Research Quarterly.(7)1. 187-203.

Creswell W. John. (2013). Research Design Pendekatan Kualitatif, Kuantitatif, dan Mixed. Yogyakarta: Pustaka Pelajar.

Demircan, Ozlen. Demir, Ayhan. (2014). Children Sense of Loneliness and Sosial Dissatisfaction, After School Care. Psychological Repprts: Mental and Physical Healt. (114) 1. 169-175.

Woodland, H. Malcolm. (2008). Watcha Doing After School? A Review of The Literature on The Influence of After School Programs on Young Black Males. Urban Education. (43) 5. 537-560.

Kaplan, Haya. 2015. Autonomous Motivation and Pro-Environmental Behaviours Among Bedouin Students in Israel: A Self-Determination Theory Perspective. Australian Journal of Environmental Education. 31(2), 223-247.

Shen, April. 2009. Self-Esteem of Young Adults Experiencing Interparental Violence and Child Physical Maltreatment: Parental and Peer Relationships as Mediators. Journal of Interpersonal Violence. 24(5), 770-794.

Brannon, Dianna. (2001) Full Day or Half Day Kindergarten: What Parents Pick and Why?. Psychology Report of Education. 71-77.

Cryan, John. Sheehan, Robert. Whiecel. Hedden. (1992). Succes Outcomes of Full Day Kindergarten: More Positive Behaviour and Increased Achievement in theYears After.Early Childhood Research Quarterly.(7)1. 187-203.

Bungin, Burhan. (2010). Analisis Data Penelitian Kualitatif. Jakarta: Rajawali Pers.

Maynard, Brandy. et.all. (2013). Fidelity in After School Program Intervention Research: A Systematic Review. Research on Social Work Practice. (23) 6. 613-623.

Vanderloo, M. Leigh. Tucker, Patricia. (2016). Physical Activity and Sedentary Time Among Young Children in Full Day Kindergarten: Comparing Traditional and Balanced Day Schedules. Healt Education Journal. (10) 1. 1-9. 
Leng. (2014). The Relationship between Self-Concept, Intrinsic Motivation, SelfDetermination and Academic Achievement among Chinese Primary School Students. Journal of Interpersonal Violence. 21(3), 362-400.

Williams. (2014). Parent Emotion Socialization Practices and Child Self-regulation as Predictors of Child Anxiety: The Mediating Role of Cardiac Variability. Child Psychiatry Hum Dev. 46(3), 512-522. 